\title{
Suicidalitet hos ensamkommande flyktingungdom med komplex traumatisering
}

\author{
Av Kristin Wahnström
}

REZA (Reza är ett fingerat namn) var en 19-årig ensamkommande ungdom från Syrien, som kom till Sverige i mars 2016. Vid de boenden där Reza blev placerad uppstod återkommande problematiska situationer. Han hamnade i konflikter och var fysiskt utagerande gentemot andra ungdomar, hotade personal till livet, slog sönder inredning, skadade sig själv genom att skära sig och hotade upprepade gånger med att ta sitt eget liv. Hans självskade- och suicidbeteende ledde till att psykiatrin uppsöktes flera gånger, ibland med inläggning inom slutenvård som fölid.

Efter åtta olika öppna placeringar blev Reza, i december 2016, akut omhändertagen för att placeras vid låst avdelning inom Statens Institutionsstyrelse, SiS. Vid första placeringen inom SiS fortsatte svårigheterna med självskadebeteenden, suicidförsök och -hot. Flera gånger beslutades om extra tillsyn utifrån oro för att Reza skulle göra sig själv illa. Efter ytterligare en omplacering ankom Reza, i mars 2017, till en låst avdelning hos oss på SiS ungdomshem Sundbo. Ungdomshemmet ligger på landsbygden utanför orten Fagersta, omkring 20 mil nordväst om Stockholm.

Reza hade redan ett par dagar efter ankomst, uttryckt önskemål om att få träffa psykolog för att han mådde dåligt. I första samtalet beskrev han tydliga symtom på trauman såsom flashbacks, mardrömmar,

dissociativa symtom och undvikanden. Utifrån hans livshistoria blev det tydligt att det rörde sig om en komplex traumatisering. Vid ett tillfälle på avdelningen tog han ett skosnöre och gick in på rummet. Då personal strax efteråt kom efter hade han dragit snöret hårt runt halsen och uttalade att han inte vill leva. Vid ytterligare ett tillfälle skar han sig i armen. I samtalen med mig uttryckte han återkommande dödsönskningar och vid några tillfällen även suicidtankar och -önskningar. Han uttryckte dock aldrig tydliga planer för hur ett eventuellt suicidförsök skulle gå till. Dessa samtal var känslomässigt laddade; ilska, frustration och sorg fick utlopp om vartannat. De fick ta tid, ibland upp till två timmar, och de

Strategierna handlade vanligen om att uppmärksamma Reza på vilken personal han kände sig trygg att samtala med samt när och hur han skulle kunna vända sig till dem. innehöll ofta pauser. Innan avslut fanns alltid överenskommelser om uppföljning, vanligen dagen efter, samt strategier för att hantera den närmsta tiden. Strategierna handlade vanligen om att uppmärksamma Reza på vilken personal han kände sig trygg att 
samtala med samt när och hur han skulle kunna vända sig till dem. I möjligaste mån försökte jag få Reza att ta initiativ till att avsluta samtalen, för att inge en känsla av tillfredställelse och kontroll. Suicidbedömningarna pendlade mellan låg- och medelrisk. Ju längre kontakten förlöpte, desto lägre bedömdes risken överlag. Samtalskontakten tycktes ge effekt, inte minst beroende på det allt större ömsesidiga förtroendet.

Jag och Reza träffades en gång i veckan för samtal, ibland oftare vid akuta fall utifrån önskemål ifrån honom. På grund av den akuta situationen och den begränsade tiden hos oss låg fokus på strategier för överlevnad och känsloreglering, medan psykoterapeutisk behandling av traumatiska situationer fick stå tillbaka. Jag och Reza träffades runt 20 tillfällen under de dryga fem månader som han var hos oss. Mot slutet av kontakten fanns en planering att han skulle flytta till ett öppet lägenhetsboende. Detta var möjligt eftersom hans självskade- och suicidbeteende hade minskat markant. Hans förmåga att hantera starka känslor hade därtill förbättrats avsevärt.

Den sista tiden för vår samtalskontakt präglades av Rezas oro för framtiden. Han var rädd för att flytta till ett öppet boende, där han misslyckats så många gånger tider. Likaledes hade han svårt att vänja sig vid tanken på att lämna Sundbo ungdomshem, ett hem där han enligt egen utsago kände sig både trygg och förstådd. Vi ägnade mycket tid åt att diskutera fördelarna med att lämna en låst institution för ett öppet boende och hur en sådan flytt svarade mot Rezas långsiktiga mål i livet. Därtill fick han möjlighet att flytta ifrån oss gradvis, genom besök och så småningom övernattning i det nya hemmet. Flytten skedde slutligen lagom till skolstart, i augusti 2017. Vid uppföljning drygt två månader senare hade Reza kunnat anpassa sig till den friare och mer ansvarskrävande behandlingsformen. Han kämpade fortfarande med sitt dåliga mående, men gick i skolan, bodde i sin stödlägenhet och var redo att inleda en psykologkontakt för att bearbeta sina traumatiska upplevelser.

\section{Användning av modeller}

Reza beskrev initialt att han mådde mycket dåligt. Han påmindes om tidigare traumatiska situationer i form av tankar och flashbacks dagtid och/eller mardrömmar nattetid. Dagtid kände han ofta att han förlorade kontrollen framför allt i konfliktsituationer och var då mycket orolig för att han skulle skada sig själv eller andra.

\section{Femfaktormodellen}

Vi använde oss av denna modell för att öka hans förmåga till introspektion och för att kunna både följa och prata om processer av känslor, tankar, beteenden 
och kroppsliga förnimmelser i olika situationer. Särskilt fokus låg på att hitta alternativa beteenden i stunder med risk för självskada. Reza tyckte det var svårt att hitta ord för dessa svåra situationer, eftersom han då inte kunde tänka på något annat. Vi började därför genomföra modellen även på andra, positiva känslor och situationer. Det gick bättre. Reza beskrev med stolthet hur han under uppmuntrande hejarop från ungdomar och personal hoppade från det tio meter höga hopptornet. Han kunde med lätthet placera sina positiva upplevelser i modellen.

Reza uttryckte dock att han inte upplevde modellen som hïälpsam i de stunder han mådde riktigt dåligt, då han hävdade att han i dessa stunder aldrig skulle kunna styra sitt beteende. Genom personalens behandling och bemötande på avdelningen sågs dock framsteg i detta, exempelvis genom att han aktivt började välja miljöombyte i svåra stunder. Dessa framsteg bekräftades i psykologkontakten genom femfaktormodellen. Det var framförallt så jag upplevde modellen som användbar; att den fick fungera som en hïälp för att strukturera upp svåra situationer i efterhand. Jag har även kunnat använda den på det sättet i handledning av personal.

Traditionellt används femfaktormodellen för att hiälpa klienten att identifiera och förstå inre beteenden för att därigenom kunna ändra sitt yttre beteende i valda situationer. I den beskrivna samtalskontakten giorde jag dock tvärtom. Jag använde konkreta förändringar i yttre beteenden för att diskutera känslor, tankar och kroppsliga förnimmelser i samma situationer. Resultatet blev detsamma: en större förmåga att observera och hantera inre beteenden. För personer som har en benägenhet för konkret tänkande och/ eller språksvårigheter kan det sistnämnda tillvägagångssättet förmodligen vara att föredra.

\section{Problemlösning}

Reza återkom till att han inte kunde bestämma om livet var värt att leva eller inte. Det som talade emot var att han varit med om så jobbiga händelser och att han inte såg någon ljus framtid. Hans familjesituation var oerhört problematisk med en bror som misshandlat honom och som Reza kände stor rädsla inför. Denne bodde också i Sverige. Han hade även flera systrar i Sverige, men hade ingen kontakt med dem utifrån att han inte ville att de skulle veta var han bodde. För honom var det ett stort misslyckande att ha hamnat i institutionsvård och han skämdes också mycket för sina våldsamma beteenden mot sig själv och andra. Vi använde oss av problemlösning för att fundera över hur han skulle kunna prata med sina syskon om det som hänt, för att i framtiden kunna ha ärliga relationer till dem. Familien var viktig för Reza och var därför en viktig komponent i viljan att leva. Man kan dock sällan ändra på andra men möjligen på sig själv. Man kan t ex förändra sina egna föreställningar om andra, vilket kallas kognitiv omstrukturering.

\section{Kognitiv omstrukturering.}

Reza hade en mycket stark oro för att andra i framtiden skulle vara rädda för honom utifrån att han suttit på institution samt hade tydliga skärsår på armen. Denna fruktan var skäl för honom att inte vilja leva. Här arbetade vi med kognitiv omstrukturering genom att exempelvis låta honom beskriva hur han såg på andra människor med liknande problematik. Reza fick även genomföra en del beteendeexperiment i anslutning till detta, där han frågade personalen om deras föreställningar om honom.

Dessa insatser föll väl ut. I synnerhet beteendeexperimenten hade en kraftfull effekt. Detta var i en period där Reza mådde relativt bra, vilket förmodligen giorde att han inte så ofta fastnade i negativa tankar (negativ selektion) efter ett beteendeexperiment. Han valde exempelvis inte längre den negativa inre kommentaren att «den personalen ville säkert bara vara snäll», utan kunde i stället ta till sig den positiva informationen att personalen menade vad hen sa.

Senare, i samtalet för uppfölining, omkring två månader efter att Reza lämnat institutionen visade det sig att han hade kunnat övervinna föreställningarna att hans två systrar skulle vara arga och avvisande och vågat träffa dem, vilket fungerade bra. De hade tvärtom varit glada att få återförenas med sin bror.

\section{Andra tankestrategier}

Reza hade stora problem med tankestrategierna förstoring och katastrofering. Den förra tankestrategin handlar om att förstora och överdriva den negativa betydelsen av egenskaper, erfarenheter eller händelser. Katastrofering innebär en vidareutveckling,

Efterhand förstod jag vikten av att låta honom exponeras för känslorna i såväl samtalen som i själva händelserna. där banala händelser och framtida tänkta scenarios får katastrofala fölider. Reza kunde återkommande gå upp i varv kring fantasier om hur framtida scenarios skulle utspela sig och han kunde bli arg, hotfull och ledsen i

samtalen då han föreställde sig händelser - det var som att han verkligen upplevde dem i stunden. Vi samtalade om tankestrategierna, men med dålig effekt.

Efterhand förstod jag vikten av att låta honom exponeras för känslorna i såväl samtalen som i siälva händelserna. Det kunde exempelvis röra sig om en konflikt med en personal, där han menade att om han återigen måste möta denna skulle han återfalla i gamla beteendemönster med våldsamheter. Den imaginära exponeringen blev viktigt för att kunna våga genomföra exponeringen in vivo, d.v.s. i verkliga livet. Denna exponering kunde i sin tur följas upp i efterhand och bl.a. nyttjas i arbetet med kognitiv omstrukturering. 


\section{Sammanfattning}

Reza hade en traumatisk historia bakom sig med bl.a. våld och död i familien samt en ensam flykt från ett krigsdrabbat Syrien. I Sverige kom händelserna ikapp honom. Underskottet på trygghet och förståelse från omgivningen i kombination med en bristfällig känsloreglering och ett dåligt psykiskt mående skapade ett kaos kring Reza. En stark motivation, en känsla av trygghet och en hög tilltro till såväl personal som samtal möjliggiorde en förändring. Samtalsterapin fokuserade på att lära ut konkreta strategier för känsloreglering och hantering av konfliktfyllda situationer. Vidare validerades Rezas upplevelser och sattes i sammanhang. Hans suicidala beteende minskade snabbt och förmågan att förstå och hantera konflikter ökade. Reza hade därmed tagit de första stegen mot en mer normal vardag.

\section{Velkommen til Fordypningskurs i DBT-ferdigheter}

Oslo, 23.-24. mai 2019

\section{MÅLGRUPPE: DBT-terapeuter}

TEMA: Hvordan anvende DBT-ferdighetene $i$ individualterapi og i gruppe slik at de passer den enkelte pasients utfordringer?

Kursets forelesere er Jennifer Sayrs, Ph.D. Hun leder DBT Center i Seattle og jobber i tillegg ved BTECH, Linehan Institute. Sayrs er en erfaren DBT-lærer og har vært forskningsterapeut og adherencekoder i flere kliniske DBT-studier. I tillegg foreleser NSSFs førsteamanuensis Anita J. Tørmoen, Ph.D.

Les mer og meld deg på: www.dbt.no

Kurset koster kr 3500.

$\mathrm{Da}$ er deltakelse,

materiell og lunsj

begge dager inkludert.

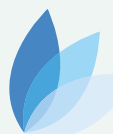

DBT DIALEKTISK ATFERDSTERAPI 